\title{
NKAIN2 Gene
}

National Cancer Institute

\section{Source}

National Cancer Institute. NKAIN2 Gene. NCI Thesaurus. Code C98050.

This gene may play a role in cation transport. 